\title{
PENGARUH EKSTRAK ETANOLIK ATAU EKSTRAK DEKOK GANODERMA LUCIDUM ( $\beta$ Glucan) TERHADAP HORMON TESTOSTERON, SEL LEIDIQ TESTIS RATTUS NORVEGICUS JANTAN.
}

(The Effect Of Ethanolic Extracts Or Dekok Of Gododerma Lucidium ( $\beta$ Glucan) Extracts On Testosteron Hormones, Sel Leidiq Testis Rttus Norvegicus)

\author{
Bambang Wasito Tjipto ${ }^{1)}$
}

\begin{abstract}
The process of "aging" causes a decline in physical and mental strength. In general, more and more bodily organs are complained of by elderly people, and suffer from chrnic diseases. Older men experience various changes including a decrease in endocrine, cardiovascular, neurological, eye, skin, reproductive and so on. The Late Onset Hypogonadism (LOH) is a syndrome that decreases sexual, physical, and psychological abilities associated with a decrease in testosterone levels in the blood. In middle age, the age of 45-59 years begins to decrease body function, including decreased reproductive function and the function of sexuality, hormones such as testosterone. which is known as aging process. Testosterone is an anabolic hormone. Giving Ganoderma Lucidum in a preliminary study of normal one-year-old male Rattus norvegicus rats, water extract (dekok) and ethanol extract with different doses, $10 \mathrm{mg} /$ $\mathrm{kg}, 20 \mathrm{mg} / \mathrm{kg} \mathrm{bw}$, and $30 \mathrm{mg} \mathrm{kg} / \mathrm{bb}$ proved to increase total testosterone hormone serum significantly at a dose of $30 \mathrm{mg} / \mathrm{kg}$ bw, then researchers increase the dose to $50 \mathrm{mg} / \mathrm{kg} \mathrm{bw}$. Purpose of the study: Analyzing the effect of dekok extract or Ganoderma lucidum ethanolic extract on the hormone testosterone, testicular Leidiq cells that are undergoing the aging process. Results: Test profile of testosterone, after administration between controls, extract of dekok and male ethanol extract of 18 months old male Leydig Rattus norvegicus testis. In different tests on testosterone, there were significant differences between controls, dekok extract and ethanol extract. The results of testosterone levels in ethanol extract were higher. Conclusion: Dekok and Ganoderm lucidum ethanol extract can increase testosterone hormone.
\end{abstract}

Keywords: LOH, Ganoderma Lucidum, Testosterone Hormone. 


\section{ABSTRAK}

Proses "penuaan" menyebabkan penurunan kekuatan fisik dan mental. Secara umum, semakin banyak organ tubuh yang dikeluhkan oleh orang tua, dan menderita penyakit kronis. Pria yang lebih tua mengalami berbagai perubahan termasuk penurunan endokrin, kardiovaskular, neurologis, mata, kulit, reproduksi dan sebagainya. Late Onset Hypogonadism (LOH) adalah sindrom yang menurunkan kemampuan seksual, fisik, dan psikologis yang terkait dengan penurunan kadar testosteron dalam darah. Di usia paruh baya, usia 45-59 tahun mulai mengalami penurunan fungsi tubuh, termasuk penurunan fungsi reproduksi dan fungsi seksualitas, hormon seperti testosteron. yang dikenal sebagai proses penuaan. Testosteron adalah hormon anabolik. Pemberian Ganoderma Lucidum dalam studi pendahuluan pada tikus Rattus norvegicus jantan normal berumur satu tahun, ekstrak air (dekok) dan ekstrak etanol dengan dosis berbeda, $10 \mathrm{mg} / \mathrm{kg}, 20 \mathrm{mg} / \mathrm{kg}$ bb, dan $30 \mathrm{mg} \mathrm{kg} / \mathrm{bb}$ terbukti meningkatkan total hormon testosteron serum secara signifikan pada dosis $30 \mathrm{mg} / \mathrm{kg}$ bb, maka peneliti meningkatkan dosis menjadi $50 \mathrm{mg} / \mathrm{kg}$ bb. Tujuan penelitian: Menganalisis pengaruh ekstrak dekok atau ekstrak etanol Ganoderma lucidum terhadap hormon testosteron, sel Leidiq testis yang sedang menjalani proses penuaan. Hasil: Profil uji testosteron, setelah pemberian antar kontrol, ekstrak dekok dan ekstrak etanol jantan dari Leydig Rattus norvegicus testis jantan berumur 18 bulan. Dalam tes yang berbeda pada testosteron, ada perbedaan yang signifikan antara kontrol, ekstrak dekok dan ekstrak etanol. Hasil kadar testosteron dalam ekstrak etanol lebih tinggi. Kesimpulan: Ekstrak etanol Dekok dan Ganoderm lucidum dapat meningkatkan hormon testosteron.

Kata Kunci: LOH, Ganoderma Lucidum, Hormon Testosteron.

1) Departemen Biologi, Fakultas Kedokteran Universitas Katholik Widyamandala Surabaya, Jl. Raya Kalisari Selatan No. 1 Tower A Lt. 7 Pakuwon City Surabaya, Email korespondensi: baratawasito@yahoo.co.id

\section{PENDAHULUAN}

Proses "penuaan" menyebabkan kemunduran kemampuan fisik dan mental. Secara umum, para usia lanjut banyak mengalami gangguan organ tubuh, dan menderita penyakit kronis. Pria usia lanjut mengalami bermacam-macam perubahan termasuk penurunan fungsi endokrin, kardiovaskuler, penyakit saraf, mata, kulit, reproduksi dan sebagainya.

Perubahan pada pria usia lanjut terutama meliputi penurunan produksi hormon androgen. Androgen ditemukan relatif lebih banyak pada pria dibanding wanita, karena hormon ini bertanggung jawab pada penampilan fisik seksualitas 
pria. Pada wanita jumlah hormon androgen lebih sedikit. Bila terjadi penurunan hormon androgen akan mempunyai efek metabolisme secara fisiologis pada beberapa sistem antara lain otak, jantung, dan sendi ${ }^{24}$, hormon testosteron sangat berpengaruh terhadap tanda seks sekunder pada laki-laki terjadiperubahan suara menjadi besar, bahu dan dada lebih lebar, juga rambut pada bagian tubuh tertentu menjadi tumbuh, contohnya: rambut kumis, janggut, jambang, ketiak, dan rambut sekitar organ reproduksi.

Late Onset Hypogonadism (LOH) adalah sindrom menurunnya kemampuan seksual, fisik, dan psikologis yang dikarenakan berkurangnya kadar hormon testosteron dalam darah. Pada pria usia pertengahan usia 45-59 tahun mulai terjadi penurunan fungsi tubuh, termasuk menurunnya fungsi reproduksi dan hormon-hormon seperti hormon testosteron. Penurunan kadar hormon testosteron pada usia 55 tahun ke atas menunjukan perbedaan yang bermakna jika dibandingkan dengan kadar hormon testosteron 12 tahun sebelumnya. Sesuai dengan bertambahnya usia tersebut maka produksi hormon testosteron juga mengalami penurunan, yang dikenal sebagai aging process. Testosteron merupakan hormon anabolik. Dengan meningkatnya usia harapan hidup maka meningkat pula jumlah lansia di masa yang akan datang, hal ini tentu berakibat semakin meningkatnya problema lansia tersebut ${ }^{5,12}$,
Ganoderma lucidum adalah obat terkenal pada pengobatan oriental berabad-abad lamanya. Ganoderma lucidum di negara Cina "Lingzhi" sedang di negara Jepang disebut "Reishi", di Indonesia dikenal dengan sebutan jamur kayu. Jamur ini telah dikenal sebagai obat tradisional, yang digunakan di Cina dan Jepang untuk pengobatan beberapa penyakit, seperti hepatitis, hipertensi, bronkitis kronis, asma bronkial, kanker dan lain-lain ${ }^{2,10}$. Sebuah studi yang menunjukkan bahwa antioksidan, dalam plasma meningkat setelah konsumsi Ganoderma Lucidum, selama 10 hari dikaitkan dengan kecenderungan profil biomarker PJK (Penyakit Jantung Koroner). Pada penelitian toksisitas jangka panjang, tikus dibagi menjadi tiga kelompok diberi Ganoderma lucidum kapsul dengan dosis 0,47, 0,94 dan 1,87, g / kg. selama dua puluh enam minggu, tidak ditemukan kelainan yang disebabkan oleh kapsul Ganoderma lucidum ( $\beta$ glucan) pada semua hasil, dan pada semua organ utama normal. Tidak ada toksisitas kapsul Ganoderma lucidum yang diberikan kepada tikus untuk jangka panjang ${ }^{9}$. Ganoderma lucidum dilaporkan mengandung beberapa komponen biologis aktif, seperti polisakarida, protein, sterol, triterpen, peptida, asam amino, asam oleat, adenosin, vitamin dan mineral. Vitamin yang dikandung diantaranya $B 1, B 2, C$, biotin, dan niacin. Sedangkan kandungan mineralnya meliputi kalium, kalsium, 
magnesium, fofor, tembaga, germanium dan beberapa makroelemen lain yang seluruhnya mencapai lebih dari 200 elemen aktif $^{2}$.

\section{METODE PENELITIAN}

Penelitian ini merupakan studi eksperimental acak, terdiri dari 3 kelompok masing -masing kelompok terdiri dri 9 ekor rattus norvegicus jantan 18 bulan, kelompok 1. merupakan kelompok kontrol diberi makan dan minum ad libitum, kelompok 2 diberi makan dan minum serta diberi ED (Ekstrak Dekok) $50 \mathrm{mg} / \mathrm{kg}$ BB kedalam 2 $\mathrm{ml}$ aqua bides, kelompok 3 diberi makan dan minum serta diberi EE (Ekstrak Etanolik) 50 $\mathrm{mg} / \mathrm{kg}$ BB kedalam $2 \mathrm{ml}$ aqua bides.

\section{Bahan penelitian}

Bahan ekstrak etanolik dan dekok diperoleh dari PT. Sahabat Lingkungan Hidup, bahan Ganoderma lucidum telah dibudidayakan di kecamatan Pare kabupaten Kediri, dan telah diidentifikasi LIPI (Lembaga Penelitian Indonesia) dan Pusat Penelitian Biologi ( Research center for Biology ) pada tanggal 23 Januari 2015, Jamur tersebut benar merupakan Ganoderma lucidum (Curtis) P. Karst merupakan suku Ganodermataceae. sertifikat identifikasi terdapat pada lampiran. Bahan ekstrak dekok diambil dari jamur $G$ Lucidum dihaluskan, menggunakan teknologi bahan ekstraksi air, dan ekstrak etanolik Ganoderma lucidum Polisakarida Peptida bahan berasal dari micellium jamur Ganoderma lucidum, menggunakan teknologi bahan ekstraksi etanol . specifikasi tentang komposisi dan kandungan ekstrak, di peroleh dari PT Sahabat Lingkungan Hidup, dan bahan untuk pemeriksaan Hormon testosteron, diperoleh dari Santa Cruz Biotechnolory, INC, USA. Tikus rattus norvegicus umur 15 bulan, berat badan antara : 250-300 gram, dalam keadaan sehat, ciri-ciri bermata jernih berwarna merah, pergerakannya aktif, dan gesit. dibeli dari Peternakan kucing dan tikus Drh. Rachmad Priyadi, Sidoarjo.

\section{Penelitian pendahuluan}

Apabila dari penelitian pendahuluan pada ekstrak etanolik dan dekok G lucidum pada rattus norvegicus 12 bulan, terjadi peningkatan hormon testosteron, dilakukan di laboratorium hewan Fakultas Farmasi Universitas Katholik Widyamandala Surabaya, menggunakan kit hormon testosteron metode elisa, maka akan dilakukan penelitian lebih lanjut.

Tabel 2.1 Penelitian pendahuluan dengan dosis 10, 20,30 mg/kgBB Ekstrak Dekok atau Ekstrak Etanolik

\begin{tabular}{lll}
\hline Kelompok & (Testosteron) $\mathrm{pg} / \mathrm{ml}$ & Analisa \\
Kontrol & $\mathbf{3 9 , 5 2 5} \pm \mathbf{0 , 1 0}$ &
\end{tabular}




\begin{tabular}{lll}
\hline Ekstrak Dekok & $\mathbf{4 7 , 7 3} \pm \mathbf{0 , 3 2 4}$ & $\geq \mathbf{3 0} \mathbf{~ g g} / \mathbf{m l}$ \\
$10 \mathrm{mg} / \mathrm{kgBB}$ & $\mathbf{1 9 8 , 1 0} \pm \mathbf{0 , 2 5 1}$ & \\
$20 \mathrm{mg} / \mathrm{kg} \mathrm{BB}$ & $\mathbf{6 1 4 , 8 0} \pm \mathbf{0 , 1 2 2}$ & \\
$30 \mathrm{mg} / \mathrm{kg} \mathrm{BB}$ & & $\geq \mathbf{3 0} \mathbf{~ p g} / \mathbf{m l}$ \\
& \\
Ekstrak & $\mathbf{6 4 , 6 9} \pm \mathbf{0 , 1 2 3}$ & \\
Etanolik & $\mathbf{1 2 8 , 4 0} \pm \mathbf{0 . 2 5 0}$ & \\
$10 \mathrm{mg} / \mathrm{kgBB}$ & $\mathbf{5 2 5 , 9 0} \pm \mathbf{0 . 0 2 1}$ & \\
$20 \mathrm{mg} / \mathrm{kgBB}$ & & \\
$30 \mathrm{mg} / \mathrm{kgBB}$ & & \\
\hline
\end{tabular}

\section{Tempat dan waktu penelitian}

Dilakukan di bagian biokimia

Fakultas Kedokteran Universitas Brawijaya

Malang oktober 2014.Untuk melakukan penelitian pengaruh ED (Ekstrak Dekok) dan EE (Ekatrak Etanol) Ganoderma
Lucidum terhadap, jumlah hormon testosteron, sel Leidiq testis.

Matrix kegiatan penelitin, meliputi definisi operasional, metodologi, waktu pengamatan, satuan yang digunakan dan analisa dapat dilihat pada tabel 2.2

Tabel 2.2 Matrix penelitian.

\begin{tabular}{lllll}
\hline Variabel & $\begin{array}{l}\text { Metode } \\
\text { pemeriksaan }\end{array}$ & $\begin{array}{l}\text { Waktu } \\
\text { pengamatan }\end{array}$ & Satuan & Analisa \\
\hline $\begin{array}{c}\text { 1. Testosteron sel } \\
\text { Leidiq }\end{array}$ & IHC & Hari ke 21 & $\begin{array}{l}\text { numerik/ rata-2 } \\
\text { dari 10 Lap } \\
\text { pandan }\end{array}$ & $\begin{array}{l}\text { varian uji } \\
\text { LSD }\end{array}$ \\
& & & \\
\hline
\end{tabular}

Hormon testosteron Leidiq, setelah diberi perlakuan ekstrak etanolik dan dekok diamati pada hari ke 21. Alat yang digunakan: Imuno histokimia. Kit yang digunakan untuk pemeriksaan Imunohistokimia menggunakan antibodi monoclonal ELISA Kit, (5E801): sc-73144, Santa Cruz Biotechnolory, INC.
Setelah sediaan slide testis dibawah pengecatan $\mathrm{H} 2 \mathrm{O} 2$, preparat di masukan kedalam incubator $37^{\circ} \mathrm{C}$ selama 24 jam.

1. Dilakukan deparafinisasi menggunakan Xilol dan alkohol berseri, simpan dalam $4^{0}$ C sampai dilakukan imunostaining (kulkas).

2. Bilas dengan $\mathrm{dH} 2 \mathrm{O}$ selama 5 menit dan lakukan pencucian dengan cairan PBS Ph: 7,4 satu kali selama 5 menit, dan tiriskan. 
3. Dilakukan Bloking endogenous peroksida mengunakan $3 \% \mathrm{H} 2 \mathrm{O} 2$ selama 20 menit. Cuci menggunakan PBS pH 7,4 tiga kali, selama 5 menit. Bloking unspesifik protein menggunakan 5\% FBS yang mengandung $0,25 \%$ Triton X 100. dan cuci menggunakan cairan PBS ph 7,4 sebanyak tiga kali, selama 5 menit.

4. Inkubasi menggunakan monoklonal anti testosteron, selama 24 jam pada $4^{0} \mathrm{C}$.

5. Cuci menggunakan cairan PBS $\mathrm{pH} 7,4$ tiga kali, selama 5 menit, kemudian

$$
\text { dilakukan inkubasi }
$$
menggunakan anti mouse biotin conjugated selama 2 jam.

6. Bilas menggunakan dH2O dan keringkan dan anginkan. Mounting menggunakan entelen dan tutup dengan coverglass.

7.Amati dibawah mikroskop cahaya pembesaran 1000 X.Dihitung sel sel warna biru. Hasil pemeriksaan immuno histokimia dihitung sel berwarna biru di bawah mikroskop cahaya menggunakan pembesaran $1000 \mathrm{X}$ sel sel warna biru. Dihitung sebanyak 10 lapang pandang, hasilnya di rata rata.

\section{HASIL PENELITIAN}

Penelitian hormon testosteron sel Leidiq testis tikus rattus norvegicus setelah diberi perlakuan Ekstrak etanol atau dekok Ganoderma Lucidum (B Glucan)

\section{Hasil setelah diberi perlakuan}

Pada saat perlakuan kelompok tikus kontrol (kelompok A). tikus tidak diberi perlakuan hanya diberi makan dan minum, kelompok B, tikus diberi makan ekstrak air PSP (Poli sakarida Peptida) dari jamur Ganoderma lucidum sebanyak $2 \mathrm{ml}$ setiap hari melalui sonde mulut selama 21 hari, pada kelompok $\mathrm{C}$ tikus diberi makan ekstrak etanol PSP dari jamur Ganoderma lucidum sebanyak $2 \mathrm{ml}$ setiap hari melalui sonde mulut selama 21 hari,

\section{Hasil uji hormon testosteron}

Hasil perbandingan produksi hormon testosteron organ testis secara Imunohistokimia menggunakan anti bodi monoclonal testosteron, ELISA Kit (5E801): sc-73144, Santa Cruz Biotechnolory, INC. (spesifikasi lihat pada lampiran) setelah perlakuan ekstrak etanolik dan dekok, selama 21 hari preparat dilihat di bawah mikroskop cahaya dengan pembesaran 1000X sebanyak 10 lapang pandang dan di rata-rata, maka dihasilkan numerik sel/lap pandang. Hasil terlihat pada gambar 1 sebagai berikut: 


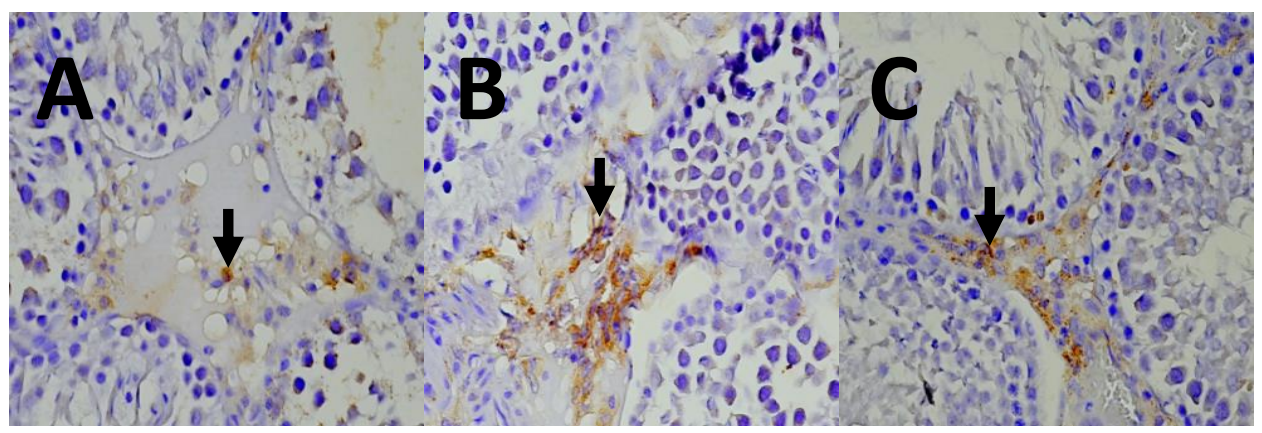
A.Kontrol
B. Dekok .
C. Etanolik

Gambar 1. Hasil perbandingan produksi hormon testosteron secara Imunohistokimia menggunakan antibodi monoclonal testosteron, ELISA Kit,(5E801): sc-73144, Santa Cruz Biotechnolory, INC. sel Leydig testis, dihitung di bawah mikroskop dengan pembesaran 1000X, sebanyak 10 lapang pandang di rata rata kelompok ekstrak etanolik (C) sel testosteron berwarna biru lebih banyak dibanding dekok (B).

Dari uji testosteron sel Leydig secara Imunohistokimia, menggunakan analisis varian ketiga kelompok hasilnya dapat dilihat pada Tabel 2.3.

Tabel 2.3.Hasil uji beda produksi Testosteron menggunakan analisis Varian

\begin{tabular}{lccc}
\hline \multicolumn{1}{c}{ Kelompok } & $\mathrm{n}$ & Rerata \pm Simpangan baku(sel) & Nilai $\mathrm{p}$ \\
& & & \\
\hline Kontrol & 9 & $3,67 \pm 1,803^{\mathrm{a}}$ & \\
Dekok & 9 & $10,89 \pm 2,088^{\mathrm{b}}$ & $<0,0001$ \\
Ekstrak etanolik & 9 & $15,44 \pm 5,270^{\mathrm{c}}$ &
\end{tabular}

Keterangan: Superscript yang berbeda menunjukkan perbedaan bermakna berdasar hasil uji LSD

\section{DISKUSI}

Kemampuan gaya hidup dan perubahan lingkungan untuk mempengaruhi kesehatan reproduktif adalah bidang yang menarik dan relevan dari penelitian. Sel-sel Leydig bertanggung jawab untuk produksi testosteron dalam testis mamalia. Produksi testosteron tergantung pada stimulasi sel-sel ini oleh LH yang disekresi dalam pulse ke dalam sirkulasi perifer oleh kelenjar hipofisis (pituitary) bawah otak dalam menanggapi GnRH dari hipotalamus. Testosteron dan produk aromatase-nya, estradiol, kemudian memberi masukan kembali ke hipotalamus dan pituitary untuk menekan produksi, secara sementara, LH dan dengan demikian testosteron. Menanggapi berkurangnya testosterone, 
GnRH dan LH diproduksi lagi. Siklus masukan negatif ini (negative feed back) menghasilkan sekresi pulsatile LH yang diikuti oleh produksi pulsatile testosteron ${ }^{4,6}$. Selama kehidupan manusia laki-laki, penurunan serum testosteron biasanya dimulai pada dekade kelima ${ }^{4,6}$, Pada manusia, penurunan tersebut disertai dengan peningkatan kadar serum FSH dan peningkatan atau tidak berubahnya tingkat $\mathrm{LH}^{28}$. Pengamatan ini, meskipun mereka tidak mengesampingkan defisit yang berkaitan dengan usia dari sumbu hipotalamus-pituitary selama proses penuaan manusia, menunjukkan defisit testis primer. Untuk tujuan ini, kami memilih untuk mempelajari penuaan sel Leydig pada tikus Rattus Norvegicus 18 bulan sebagai model untuk manusia. Dalam ketegangan ini, pada manusia dan juga jenis tikus lainnya, kadar serum testosteron menurun seiring dengan usia.

Sejak ribuan tahun Manusia telah berburu jamur liar. Sudah lama jamur telah digunakan sebagai sumber makanan ${ }^{16}$, karena komposisi kimianya yang menarik dari sumber gizi. Pada awal peradaban, jamur dikonsumsi terutama untuk palatabilitas dan rasa unik ${ }^{20,21}$. Penggunaan jamur sama sekali berbeda dari tradisional, karena banyak penelitian telah dilakukan pada komposisi kimia jamur, yang mengungkapkan bahwa jamur dapat digunakan sebagai diet untuk mengobati penyakit.
Pada percobaan pendahuluan pada tikus putih (Rattus norvegicus) jantan usia satu tahun normal, dan diberi ekstrak etanol Polisakarida Peptida G lucidum ( $\beta$ Glucan) dengan dosis berbeda, $10 \mathrm{mg} / \mathrm{kgbb}, 20$ $\mathrm{mg} / \mathrm{kgbb}$, dan $30 \mathrm{mgkg} / \mathrm{bb}$ terbukti terjadi peningkatan kadar hormon testosteron total secara bermakna pada dosis $30 \mathrm{mg} / \mathrm{kg} \mathrm{bb}$, namun kurang optimal untuk itu dosis $\beta$ Glucan $G$ Lucidum akan ditingkatkan menjadi $50 \mathrm{mg} / \mathrm{kg}$ bb.

Antioksidan adalah senyawa kimia melindungi sel-sel dari kerusakan yang disebabkan oleh molekul tidak stabil yang dikenal sebagai radikal bebas. Radikal bebas merupakan oksidan kuat dan entitas kimia yang mengandung elektron yang tidak berpasangan. Mereka mampu secara acak merusak semua komponen tubuh, yaitu. lipid, protein, DNA, gula dan terlibat dalam mutasi dan kanker $^{18}$. Oksigen yang terperangkap oleh enzim seperti superoksida dismutase, katalase, dan glutation peroksidase. Selama produksi radikal bebas menciptakan stres oksidatif. Antioksidan adalah penting pertahanan tubuh terhadap radikal bebas dan jamur yang merupakan sumber yang kaya antioksidan $8,15,17,19$. Properti antioksidan adalah Senyawa berkorelasi dengan senyawa fenolik ${ }^{25}$. Ekstrak jamur memiliki sifat melindungi DNA $^{14}$, ekstrak Ganoderma lucidum berfungsi sebagai perangkap radikal bebas ${ }^{11}$. Telah ditemukan Sifat antioksidan dari beberapa jamur kuping ${ }^{15}$, banyak spesies jamur telah ditemukan meningkatkan 
kekebalan tubuh yang kuat, hewan dan kekebalan manusia terhadap kanker ${ }^{3,7,13,26}$. Triterpenoid adalah senyawa kimia utama pada G. lucidium. Camptothecin bertanggung jawab sebagai antioksidan di Ganoderma lucidum ${ }^{27}$.

\section{KESIMPULAN}

Penelitian ini dapat diambil suatu kesimpulan sebagai berikut: Ekstrak etanol atau dekok Ganoderma lucidum dapat menstimulasi Lutinizing hormon (LH) untuk merangsang sel Leidiq dalam memproduksi hormon testosteron.

\section{KEPUSTAKAAN}

1. Belanger A, Candas B, Dupont A, Cusan L, Diamond P, Gomez L, Labrie F.1994. Changes in serum concentrations of conjugated and unconjugated steroids in 40- to 80-year-old men. J Clin Endocrinol Metab; 79:1086-1090.

2. Boh. B, Berovic. M, Zhang. J, Zhi-Bin. L.2007. Ganoderma lucidum and pharmaceutically active compounds. Biotech. Annu. Rev. 13, 265-301.

3. Borchers AT, Stern JS, Hackman RM.1999. Mushrooms, tumors, and immunity. Proc. Soc. Exp.

Biol. Med., 221: 281-293.

4. Bremner WJ, Bagatell CJ, Christensen RB, Matsumoto AM. 1993. Neuroendocrine aspects of the control of gonadotropin secretion in men. In: Whitcomb RW, Zirkin BR (eds.), Understanding Male Infertility: Basic and Clinical Aspects. New York: Raven Press; 29-41.

5. Dotson a. 2003. Methods of Testosterone Supplementation for Man and Women Men's Health Abstract, Desember.

6. Ellis GB, Desjardins C, Fraser HM.1983. Control of pulsatile $\mathrm{LH}$ releas in male rats. Neuroendocrinology; 37:177-183.

7. Feng W, Nagai J, Ikekawa T. 2001. A clinical pilot study of EEM for advanced cancer treatment with EEM for improvement of cachexia and immune function compared with MPA. Biotherapy, 15: 691-696.

8. Ferreira ICFR, Baptista P, Vilas-Boas M, Barros L. 2007. Free-radical scavenging capacity and reducing power of wild edible mushrooms from northeast Portugal: individual cap and stipe activity. Food Chem., 100: 1511-1516.

9. Gao. J, and J. Han. 2008. Long-Term Toxicity Studies on Ganoderma lucidum capsules for drug Lishizhen Rats. 4 research and materia medica.

10. Habijani. J, Berovi. M, Wraber. B, Hodzar. D, Boh. B. 2001. Immunostimulatory

effects Polysaccharies of Ganoderma lucidum mushroom Submerged Cultivation of Biomass. Food Technol. Biotechnol, 39, 327-331.

11. Jones S, Janardhanan KK. 2000). Antioxidant and antitumor activity of Ganoderma lucidum (curt ex Fr.). P. 
Karst-Reshi (Aphyllophoromycetieae) from south India. Int. J. Med. Mushrooms, 2: 195-200.

12. Kaufman J.M, Vermeulen A. 2005. The Decline of androgen Levels in Elderly men and Its Clinical and Therapeutic Implication. Endocrine Reviews 26 (6): 833-876.

13. Kidd PM (2000). The use of mushroom glucans and proteoglycans in cancer therapy. Alternative Med. Rev., 5: 4-27.

14. Kim KC, Kim IG.1999. Ganoderma lucidum extract protects DNA from strand breakage caused by hydroxyl radical and UV irradiation. Int. J. Mol. Med., 4: 273-277.

15. Mau CN, Huang SJ, Chen CC. 2004. Antioxidant properties of methanolic extracts from Grifola frondosa, Morchella esculenta and Termitomyces albuminosus mycelia. Food Chem., 87: 111-118.

16. Mattila P, Konko K, Eurola M, Pihlawa JM, Astola J, Vahteristo Lietaniemi V, Kumpulainen J, Valtonen M, Piironen V. 2001. Contents of vitamins, mineral elements, and some phenolic compounds in cultivated mushrooms. J. Agric. Food Chem., 49: 2343-2348.

17.Puttaraju NG, Venkateshaiah SU, Dharmesh SM, Urs SM, Somasundaram R. 2006. Antioxidant Activity of Indigenous Edible Mushrooms. J. Agric. Food Chem., 54: 9764-9772.
18.Przybytniak G, Ambroz H.1999. Free radicals, their identification and determination. In: Marciniec B and Zak S., (eds.) Analytical methods in studies of pollutants and hazardous. Bydgoszcz: BTN, p. 17.

19.Oyetayo FL. 2007. Potential antioxidant properties of Nigerian edible mushrooms. Agro foodIndustry, Hi-tech., 18: 44 -45.

20.Rai RD. 1994. Nutritional and medicinal values of mushrooms. In: Advances in Horticulture. (Chadha KL, Sharma SR eds.), Malhotra publishing house, New Delhi, pp. 537-551.

21.Rai RD. 1997. Medicinal mushrooms. In: Advances in Mushroom Biology and Production (Rai RD, Dhar BL, Verma RN ed.) Mushroom society of India. NRCM, Solan, H.P., pp. 355-368.

22. Shi YL, James AE, Benzie IFF, Buswell JA. 2002. Mushroom derivedpreparation in the prevention of $\mathrm{H} 2 \mathrm{O} 2$-induced oxidative damage to cellular DNA. Teratoegensis Carcinogenesis Mutagenesis, 22: 103- 111.

23. Taher A. 2005. Proportion and Acceptance of Andropuse Symtomps Among Elderly Men: A Studlthy in Jakarta. Indones $J$ Intern Med. 37: 82-86.

24. Tan R S, Meenu J. 2005. Aging Men's Health A Case -Based A-pproarchl; Delaying Aging for Men: Longevity Lesson from Women; 11-20.

25. Velioglu YS, Mazza G, Gao L, Oomah BD 
.1998. Antioxidant activity and total phenolics in selected fruits, vegetables, and grain products. J. Agric. Food Chem., 46: 4113-4117.

26. Wasser SP, Weis AL.1999. Medicinal properties of substances occurring in higher Basidiomycetes mushrooms: current perspectives (Review). Int. J. Med. Mushrooms, 1: 1-62.

27. Zhou Z, Lin J, Yin Y, Zhao J, Sun, X, Tang K. 2007. Ganodermataceae: Natural products and their related pharmacological functions. Amer. J. Chin. Med., 35: 559-574.

28. Zwart AD, Urban RJ, Odell WD, Veldhuis JD.1996. Contrasts in the gonadotropinreleasing hormone dose-response relationships for luteinizing hormone, follicle-stimulating hormone and alphasubunit release in young versus older men: appraisal with high- specificity immunoradiometric assay and deconvolution analysis. Eur $\mathbf{J}$ Endocrinol; 135: 399-406. 